\title{
Concentrations between Non-European Enterprises and the European Merger Control Regulation
}

\author{
Nesrin SULEIMAN*
}

\begin{abstract}
This paper examines the scope of the European Merger Control Regulation (EUMR). More specifically, it traces the development of the extraterritorial application of the EUMR. Furthermore, it reviews the European Commission's assessment of concentrations between non-European enterprises. Surprisingly, concentrations with no actual foreseeable effects on the Single Market can be subject to mandatory notification. This has led to absurd cases being decided by the European Commission which will be discussed in more detail.
\end{abstract}

Keywords: European Merger Control Regulation-community dimension-extraterritorial application

\section{INTRODUCTION}

Globalization and the expansion of markets have "generated an increase in international mergers as

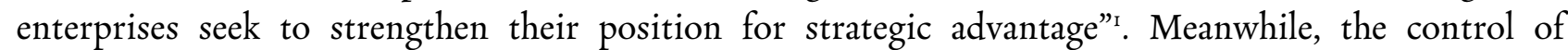
international concentrations is a key instrument of the European competition policy. In this regard, my primary concern is to explain how the European Commission does justify its competence to control international concentrations, especially those between (non-)European enterprises which do not impede the effective competition in the Single Market.

The Regulation of the Council (EC) No. 139/2004 on the control of concentration between undertakings (EUMR) ${ }^{2}$ is applicable to all concentrations with an 'EU dimension', Article I EUMR. Where a concentration has an EU dimension, Article 2I of the EUMR provides that the Member States shall not apply their national competition laws. ${ }^{3} \mathrm{~A}$ concentration will have an EU dimension if the combined aggregate worldwide turnover of all the undertakings concerned is more than 5 billion Euro and the aggregate turnover in the $\mathrm{EU}$ of each of at least two of the undertakings concerned is more than 250 million Euro, unless each of the undertakings concerned generates more than two thirds of its aggregate EU-wide turnover within a single EU country.

While analysing the European Commission's merger decisions two points stand out: first, they do not explain whether they examine the scope of the EUMR in accordance to the principles of international law. Second, they interrogate concentrations which even do not raise serious doubts as to their compatibility with the Single Market. This has led to absurd cases being decided by the European Commission and shall be discussed in more detail. However, the extraterritorial application of competition laws is frequently criticized as trespassing on the sovereignty of nation in which the

\footnotetext{
Research associate and doctoral student at the Goethe University Frankfurt (Germany); Suleiman@jur.unifrankfurt.de. With thanks to my sister Yasmin Suleiman and my colleague Fatima-Zahra Zaatan for helpful comments.

M. Utton, International Competition Policy (Elgar, Cheltenham, 2006), at. 73.

2 Commission Consolidated Jurisdictional Notice under Council Regulation (EC) No. 139/2004 on the control of concentrations between undertakings of 16 April 2008, OJ 2008 C 95/I, para. 196.

3 This is also referred to as the one stop shop approach.
} 
concentration occurs. This raises questions as: What is the appropriate scope of extraterritorial jurisdiction? How should extraterritoriality be regulated in relation to mergers? This paper examines the legal basis for extraterritorial jurisdictional claims of the EUMR and tries to identify the most appropriate way to find practical solutions for concentrations between non-European enterprises.

\section{THE EUROPEAN COMMISSION'S PRIOR DECISION PRACTICES}

The merger cases reviewed by the European Commission can be categorized into four groups: a) mergers between a non-European enterprise with an enterprise based in the European Union, b) concentrations between non-European enterprises which may significantly impede effective competition in the Single Market or in a substantial part of $\left.i t^{4}, c\right)$ joint ventures created by (non-) European enterprises be exclusively operating outside the European Union and not impeding effective competition in the Single Market; 5 and d) concentrations between two non-European enterprises obviously not impeding effective competition in the Single Market. ${ }^{6}$ Even the last two types - despite distant effects on the competition in the Single Market - have to be notified to the European Commission prior to their implementation, see Article 4 EUMR. This has led to absurd notified cases being decided by the European Commission such as a creation of a joint venture providing exclusively telecommunications services in Japan or a joint venture building a pipeline in Vietnam.

Remarkable is that a number of joint ventures have been notified which either were of insignificant economic importance or were engaged in activities outside of the European Union and having no or minimal impact within the Union. Instancing the case JCSAT/SAJAC whereby the European Commission wrote: "the concentration has presently no effect in the [Union]" and "[ $t$ ]his situation is not likely to change (...)" 7 .It is striking that the European Commission only focuses on the thresholds laid down in Article I EUMR to justify the application of the EUMR and thus its competence. The effects doctrine is not mentioned at all, not to mention the implementation doctrine. This practice meets opposition with the practice relating to Articles IOI and IO2 TFEU whereby the European Commission determines the extraterritorial application of these two articles according to the effects doctrine. Furthermore, the European Commissions' practice is inconsistent with public international law and the International Competition Network's Recommended Practices for Merger Notification Procedures $^{8}$ which both recommend the effects doctrine. The effects doctrine refers to the assertion of jurisdictional claims based solely on effects felt within the asserting jurisdictions. The ICN's Recommended Practices for Merger Notifications Procedures state as well: "[J]urisdiction should be asserted only over those transactions that have an appropriate nexus with the jurisdiction

\footnotetext{
4 E.g.: Ciba-Geigy/Sandoz (Case No IV/M.737 - Ciba-Geigy/Sandoz); Boeing/McDonnel Douglas (Case No IV/M.877 - Boeing/McDonnell Douglas); Gencor/Lonrbo (Case No IV/M.6rg - Gencor/Lonrho) and GE/Honeywell (Case No COMP/M.220 - General Electric/Honeywell). More recently: Oracle/Sun Microsystems (Case No COMP/M.5529 Oracle/Sun Microsystems) and Intel/McAfee (Case No COMP/M.5984 - Intel/McAfee).

5 E.g. four Japanese Enterprises creating a joint venture that will provide exclusively telecommunications services in Japan, see Case No IV/M.346 - JCSAT/SAJAC; Four oil/gas companies creating a joint venture to build a pipeline in Vietnam, see Case No COMP/M.6193 - TNK Overseas LTD/PVN GAS/Conocophillips/NCS Pipeline.

6 E.g. merger between two Japanese banks, see Case No IV/M.069 - Kyowa/Saitama Banks; merger between two American banks, see Case No IV/M.I37 - BankAmerica/Security Pacific).

7 Commission Decision Case No IV/M.346 - JCSAT/SAJACof 30 June I993, http://ec.europa.eu/competition/mergers/cases/decisions/m346_en.pdfp. 3, para. II f.

8 International Competition Network, Recommended Practices for Merger Notifications Procedures, available at: http://www.internationalcompetitionnetwork.org/uploads/library/doc588.pdf,last accessed on I October 2015.
} 
concerned."Even the Court of First Instance held in the case Gencor/Lonrbo'that the application of the EUMR is only justified "when it is foreseeable that a proposed concentration will have an immediate and substantial effect in the [Union]." ${ }^{\text {Io } I n d e e d, ~ i t ~ i s ~ d i f f i c u l t ~ t o ~ s e e ~ h o w ~ a ~ j o i n t ~ v e n t u r e ~}$ operating outside of the European Union could have any effects within the Union.

So in the light of the effects doctrine it has been argued that where a concentration obviously has no impact on the competition in the Single Market, there should be no notification requirement even if the turnover criteria of Article I EUMR are fulfilled. The assessment of effects on the competition in the Single Market has only been taken into account within the examination of the substantial law. Thus, the key questions being addressed in this paper are how the extraterritorial application of the EUMR is justified and whether the turnover criteria in Article I EUMR are a reasonable nexus for the extraterritorial application of the EUMR.

\section{THE EXTRATERRITORIAL APPLICATION OF THE EUMR}

The scope of the EUMR is provided in its Article I.

\section{(I) No conflicting rule}

The EUMR is applicable to all concentrations with an 'EU dimension'. Article I paragraph 2 EUMR provides that a concentration has an EU dimension where a) the combined aggregate worldwide turnover of all the undertakings concerned is more than 5 billion Euro and $b$ ) the aggregate turnover in the EU of each of at least two of the undertakings concerned is more than 250 million Euro, unless each of the undertakings concerned generates more than two thirds of its aggregate EU-wide turnover within a single EU Member State. Article I paragraph $3 \mathrm{EUMR}^{\mathrm{II}}$ intends to target concentrations involving less turnover than Article I paragraph 2 EUMR but still requiring notification in three or more Member States.

In consideration of Article I EUMR which provides the scope of the EUMR, the Regulation does not contain any provision that explicitly deals with the extraterritorial application of the Regulation.

\footnotetext{
9 Commission Decision Case No IV/M.6r9 - Gencor/Lonrboof 24 April 1996, OJ 1997 L II/30 and EGC, Case No TI02/96 (Gencor $v$ Commission), ECLI:EU:T:1999:65.

10 Commission Decision Case No IV/M.619 - Gencor/Lonrboof 24 April 1996, OJ 1997 L ir/30 and EGC, Case No TI02/96 (Gencor v Commission), ECLI:EU:T:1999:65, para. 90.

II Article I paragraph 3 EUMR provides:

"A concentration that does not meet the thresholds laid down in paragraph 2 has a Community dimension where:

(a) the combined aggregate worldwide turnover of all the undertakings concerned is more than EUR 2500 million;

(b) in each of at least three Member States, the combines aggregate turnover of all the undertakings concerned is more than EUR Ioo million;

(c) in each of at least three Member States included for the purpose of point (b), the aggregate turnover of each of at least two of the undertakings concerned is more than EUR 25 million; and

(d) the aggregate Community-wide turnover of each of at least two of the undertakings concerned is more than EUR Ioo million,

unless each of the undertakings concerned achieves more than two-thirds of its aggregate Community-wide turnover within one and the same Member State”
} 
(2) Determining the extraterritorial application of the EUMR

That is why the extraterritorial scope of the EUMR has to be determined by its rules themselves and if necessary by their interpretation. The scope of the EUMR has to be determined based on the wording and the purpose of the Regulation.

\section{(a) Recital No. Io of the EUMR}

Recital No. Io of the EUMR only makes clear that "[a] concentration with a Community dimension should be deemed to exist where the aggregate turnover of the undertakings concerned exceeds given thresholds; that is the case irrespective of whether or not the undertakings effecting the concentration have their seat or their principal fields of activity in the [Union], provided they have substantial operations there." That is to say, there is no requirement for the undertakings concerned to be domiciled in the Union, or that any part of the concentration takes place in the EU.

\section{(b) Turnover Criteria}

In the first place, Article I EUMR divides jurisdiction between the European Commission and the Member States by means of a threshold based on turnover. Therefore, the turnover criteria of Article I EUMR are "transnationality criteri[a]" Articles IOI and IO2 TFEU.

Some scholars see in the turnover criteria a clear conflict rule of the EUMR. But there are a few reasons against this view: first, the distinct wording of Article I EUMR and second, looking at the genesis of the EUMR, the originally wording - "(...) at least one of [the undertakings] is established in the common market (...)" ${ }^{\text {I3 }}$ and the introduction of a market share criterion in Article I EUMR ${ }^{14}$-were cancelled in the end. Nevertheless, the turnover criteria determine the scope of the EUMR so that concentrations between non-European enterprises implemented outside of the European Union can be reviewed as well. Thus, the quantitative thresholds based on turnover of undertakings concerned are used as a proxy for the economic resources being combined in a concentration and their geographic allocation. Even though there is not an analysis of competitive effects - at least not regarding the question of the scope of the EUMR - it can be assumed that if the undertakings exceed the thresholds laid down in Article. I EUMR the concentration will be likely to have an immediate and substantial effect on competition within the Union. Following the reasoning, the turnover criteria can be seen as a hidden rule of conflict of law. Is

To sum up, the turnover criteria of Article I EUMR serve a dual purpose: first, in the spirit of subsidiarity, they serve to divide the competence to assess concentrations between the European Commission and the National Competition Authorities. In addition, they are hidden rules of conflict of the EUMR.

\footnotetext{
I2 L. Davison/ E. Fitzpatrick, "An assessment of Community interest, Community dimension and decentralisation in EU competition policy”, European Business Review (1998) I60-167 [DOI: I0.1108/09555349810213230], at I65.

13 See: Commission Proposal for a Regulation (EEC) of the Council on the control of concentrations between undertakings of 31 October 1973 , OJ 1973 C 92/I, at 2.

${ }^{14}$ See: Commission Amended proposal for a Council Regulation on the control of concentrations between undertakings (merger control Regulation) of 12 February 1982, OJ 1982 C 36/3, at 4-5 and Commission Amendment to the proposal for a Council Regulation on the control of concentrations between undertakings of 23 February 1984, OJ $1984 \mathrm{C}$ 5I/8, at 8-9.

is E. Rehbinder, "Internationales Wettbewerbsrecht”, in: U. Immenga/ E.-J. Mestmäcker (eds.), Wettbewerbsrecht Band I: EU/Teil I und Teil 2. Kommentar zum Europäischen Kartellrecht ( $5^{\text {th }}$ ed., Beck, München, 20I2), para. 52.
} 


\section{(3) Legal consequences}

The EU dimension of a concentration triggers off certain legal consequences: In principle, concentrations with an EU dimension shall be notified to the European Commission prior to their implementation, Article 4 EUMR. This notification requirement is associated with the suspension of concentrations, see Article 7 EUMR. By failing to notify a concentration or implementing a concentration in breach of Article 7 the European Commission may impose fines not exceeding IO\% of the aggregate turnover of the undertaking concerned, see Article I4, paragraph 2 EUMR.

\section{TURNOVER THRESHOLDS AS A REASONABLE NEXUS FOR THE EXTRATERRITORIAL}

\section{APPLICATION OF THE EUMR?}

The main question is whether the European Commission did consider the connecting factors based on general principles of public international law upon which the applicability of the EUMR is determined. Based on the 'genuine link'concept written by F.A Mann ${ }^{16}$ there has to be a genuine link between the right to regulate situations and the powers of the State or as it is here the EU. It is difficult to say in which cases when such connecting factors are reasonable to establish jurisdiction; this depends on the to be regulated field of law. ${ }^{17}$ Connecting factors which have been accepted as sufficient to establish jurisdiction in public international law are: the territoriality, the citizenship andthe effects principle. Hereafter, it is to analysewhether the existing turnover thresholds are appropriate to determine which concentrations have a Union-wide dimension.

(I) Turnover criteria: reasonable nexus in terms of the effects doctrine?

The effects doctrine which refers to the assertion of jurisdictional claims based solely on effects felt within the asserting jurisdiction is as an appropriate connecting factor accepted and recognized in public international law and competition law. But are the turnover criteria laid down in Article I EUMR a reasonable nexus in terms of the effects doctrine?

One can infer from the Union-wide turnover criteria that the application of the EUMR has a 'built-in' effects doctrine.$^{18}$ But keeping in mind that initially, the first drafts required a territorial reference to the EU and the EU-wide turnover of 250 million Euro was merely a political compromise, not provided by an economic and scientific analysis for the introduction of these particular levels, it cannot be assumed that the turnover criteria are a manifestation of the effects doctrine. Even though it cannot be denied that turnover can be a sign for effects on the competition, the exceeding of the turnover thresholds does not consequently mean that the effects doctrine is fulfilled. Therefore, the turnover criteria in Article I EUMR are not a manifestation of the effects doctrine because there is no well-founded link between the exceeding of the turnover thresholds and the effects on the competition in the Single Market. The European Commission brings forward the argument that it is necessary to

16 F. Mann, "The DoctrineofJurisdiction in International Law”, in Receuil des Cours (1964 I) I- I62, at 44-51. Mann uses as synonyms for "genuine link" as well "reasonable relation" and "closeness of connection". The term 'genuine connection' has its origins in ICJ, The Nottebohm Case (Liechtenstein v. Guatemala), Reports of Judgements, Advisory Opinions and Orders, 6 April 1955 , at 23.

${ }_{7}$ K. Meessen, “Antitrust Jurisdiction under Customary International Law", 78 American Journal of International Law (1984) 783-810, at 800 .

I8 M. Hartmann-Rüppel, Europäische Fusionskontrolle und Luftverkebr (Nomos Verlagsgesellschaft, Baden-Baden, 2002), at 89 . 
have a cursory assessment of the possible effects of a concentration on the Single Market and if there is no notification then the European Commission cannot fulfil itstasks as the European competition guardian. ${ }^{19}$ But probably, there are alternatives to the thresholds based on turnover to establish jurisdiction.

\section{(2) Possible alternatives to thresholds based on turnover}

Alternatives to thresholds based on turnover have to reflect the genuine link between the right to regulate concentrations and the powers of the EU. In addition, determining jurisdiction has to be objective and comprehensible for everyone.

Introducing other criteria to determine jurisdiction based on assets or market shares thresholds would be more appropriate but information about market shares are often unavailable or imprecise. And they can only be accurately established after extensive analysis so in the end they reduce legal certainty which is important for determining jurisdiction. ${ }^{20}$ An introduction of differentiated thresholds on a sectorial basis can be an option to the turnover criteria but it is difficult to establish varying thresholds by sector in terms of obtaining an "equivalent" measure for merger control. ${ }^{2 \mathrm{I}}$ Besides, the application of the EUMR would be more complex, particularly in cases concerning global players which are active across a number of sectors.

As the European Commission wrote: "The theoretical advantages gained by the introduction of other criteria such as sectoral or qualitative data, would therefore be considerably outweighed by the practical difficulties they would raise." ${ }^{22}$ The great advantage of thresholds based on turnover lies in the provision of a clear-cut determinant of jurisdiction.

However this situation is still unsatisfactory. It is not comprehensible that concentrations that meet the turnover thresholds have to be notified regardless of their actual effect on the competition in the EU.

Given that the European Commission does not determine the application of the EUMR in accordance with the effects doctrine, the European Commission has acted ultra vires by taking jurisdiction and accordingly, the act is void..$^{23}$ This consequently means that concentrations with actual no or minimal effect on the EU are not obliged to be notified to the European Commission and even not with the Simple Procedure Form. ${ }^{24}$ So what else can be considered? It is beyond the scope of this paper to open up this large topic. Only four points shall be mentioned without discussing them in detail:

19 D. Feeney, “The European Commission's Extraterritorial Jurisdiction over Corporate Mergers”, I9 Georgia State University Law Review (2002-2003) 425-494, at 491.

${ }_{20}$ Commission, Report from the Commission to the Council on the Implementation of the Merger Regulation, $\operatorname{COM}(93) 385$ final, para. I3; Commission Green Paper on the Review of the Merger Regulation, $\operatorname{COM}_{(96)}$ I9 final, para. I3I. For a detailed discussion on merger regulation thresholds, see Commission, Green Paper on the Review of Council Regulation (EEC) No. 4064/89, COM(200I) 745 final, Annex I - Thresholds Related Issues.

${ }_{21}$ Commission, Report from the Commission to the Council on the Implementation of the Merger Regulation, $\operatorname{COM}(93) 385$ final, para. I3.

${ }^{22}$ Commission, Report from the Commission to the Council on the Implementation of the Merger Regulation, $\operatorname{COM}(93) 385$ final, para. 13 .

${ }_{23}$ M. Broberg, Broberg on the European Commission's Jurisdiction to Scrutinise Mergers (4 ${ }^{\text {th }}$ ed., Wolters Kluwer, Alphen aan den Rijn, 2013), at 250.

24 G. Wiedemann, Drittstaaten-Zusammenschlüsse und EG-Fusionskontrollverordnung, in: E. Niederleithinger/ R. Werner/ G. Wiedemann (eds.), Festschrift für Otfried Lieberknecht zum 70. Geburtstag (Beck, München, 1997) 625 , at 636. 
- The European Commission already said that the "EU dimension" should be ideally defined on the basis of its effects on the market. ${ }^{25}$ Maybe the EUMR should be revised by including(actual or potential) effects within the requirements of Article I EUMR.

- Another option not requiring a change in the Regulation can be achieved through interpreting the EUMR in accordance with the effects doctrine by publishing guidance statements on the application of the EUMR, especially regarding issues relating to jurisdiction.

- Under Article 5 paragraph 5 EUMR the turnover of the parents are decisive, irrespective of the geographic location or the assets of the joint venture. To cure this problem it is recommendable to introduce a threshold based on the market shares of the joint venture.

- The short-form notification is applicable for cases where the turnover of a joint venture and/or the turnover of the contributed activities is less than Ioo million Euro in the EEA, and the total value of the transferred assets is less than 100 million Euro in the EEA. As to operations other than joint ventures, no market information is required where the combined market share of the parties does not exceed $20 \%$ in the same product market and any individual or combined market share does not exceed 30\% in market upstream or downstream of a product market in which any or more of the parties is active. ${ }^{26}$ It cannot be denied that these provisions reduce the burden of notification, but the establishment of a voluntary notification regime for these extraterritorial concentrations with no actual or minimal impact on the competition in the Single Market is more appropriate under certain conditions.

\section{CONCLUSION AND DISCUSSION}

Under the EUMR all concentrations that meet the turnover thresholds of Article I EUMR have to be notified regardless of their effect on the European Union. With this regulation even concentrations with no actual foreseeable effects within the Single Market can be seen subject to mandatory notification. As seen this has led to absurd cases being decided by the European Commission. This situation is unsatisfactory for several reasons. In particular, it is inconsistent with the principles of public international law and the International Competition Network's Recommended Practices for Merger Notification Procedures. For this reason, it is not sufficient if concentrations just exceed the turnover thresholds. The European Commission should rather think of determining jurisdiction by using the effects doctrine - literally.

${ }_{25}$ Commission, Green Paper on the Review of the Merger Regulation, $\operatorname{COM}(96)$ is final, para. 3I.

26 See Commission Implementing Regulation (EU) No $1269 / 2013$ of 5 December 2013 amending Regulation (EC) No 802/2004 implementing Council Regulation (EC) No 139/2004 on the control of concentrations between undertakings, OJ 2013 L336/I Annex II - Short Form CO for the Notification of a Concentration Pursuant to Regulation (EC) No I39/2004, para. I.I. 